\title{
DOSIS PUPUK KANDANG DAN UMUR PANEN PADA PRODUKSI BABY KANGKUNG (IPOMOEA REPTANS)
}

\author{
Leviana Eka Vivia Wati ${ }^{\left.{ }^{*}\right)}$, Trijono Djoko Sulistyo ${ }^{1)}$ dan Mujiyo ${ }^{2)}$ \\ ${ }^{1)}$ Program Studi Agroteknologi, Fakultas Pertanian, Universitas Sebelas Maret \\ ${ }^{2}$ Program Studi Ilmu Tanah, Fakultas Pertanian, Universitas Sebelas Maret \\ *Corresponding author: levianaeka@student.uns.ac.id
}

\begin{abstract}
The research aims to assess the yield of baby kale that can be consumed almost all of the parts and generate organic manure free. Field research was conducted in Sindon Village, Ngemplak, Boyolali in September to October 2016. The research method uses Randomized Complete Block Design factorial with two factors, these are the dosage of manure and the age of harvest. Manure consisted of 4 doses $\mathrm{O} 1$ (0 ton/ha), O2 (6 tons/ha) and $\mathrm{O3} \mathrm{(8} \mathrm{tons/ha)} \mathrm{and} \mathrm{O4} \mathrm{(10} \mathrm{tons/ha),} \mathrm{and} \mathrm{age} \mathrm{of} \mathrm{harvest} \mathrm{consisted} \mathrm{of}$ P1 (16 DAS), P2 (20 DAS), and P3 (24 DAS). Variables observed were plant height, number of leaves, internode length, fresh weight, dry weight, leaf area index, and harvest index. The result showed that age of harvest has significant influence plant height, internode length, the number of leaves, leaf area index, fresh weight, dry weight, and harvest index. Manure doses only influence dry weight. Manure dosage of $8 \mathrm{ton} / \mathrm{ha}$ and harvest age of $16 \mathrm{DAS}$ is the best combination of baby kale. Manure dosage of 10 ton/ha and harvest age of 16 DAS produce baby kale that can be consumed almost in all parts of the plant with the highest harvest index that is equal to 0.83 .
\end{abstract}

Keywords: Harvest age; Ipomoea reptans; Manure

Cite this as: Vivia, L., Sulistyo, T., \& Mujiyo, M. 2017. Dosis Pupuk Kandang dan Umur Panen pada Produksi Baby Kangkung (Ipomoea reptans). Caraka Tani: Journal of Sustainable Agriculture. 32(2), 68-74. doi: http://dx.doi.org/10.20961/carakatani.v32i2.12210

\section{PENDAHULUAN}

Kangkung darat merupakan tanaman sayuran yang sudah tidak asing di kalangan masyarakat. Kangkung darat memiliki banyak manfaat dan kandungan gizi sehingga banyak digemari oleh semua kalangan (Polii, 2009). Menurut Nurjanah et al. (2014) hampir keseluruhan tanaman muda dari kangkung darat dapat dikonsumsi terutama bagian pucuk muda yang lebih banyak di gemari. Hal ini dikarenakan kangkung darat yang tua kebanyakan bagiannya berserat dan kasar sehingga berpengaruh terhadap rasa yang kurang enak (Edi dan Yusri, 2009). Kenyataannya, saat ini kangkung darat yang beredar di pasaran memiliki nilai kurang baik dikarenakan banyak bagian yang sudah tua dan tidak dikonsumsi. Bagian yang dapat dikonsumsi hanya sekitar 45$55 \%$, sedangkan hampir 50\% nya dibuang atau untuk pakan ternak.

Melihat fakta tersebut, perlu adanya tindakan dan inovasi mengenai budidaya kangkung darat. Penelitian ini bertujuan untuk mengetahui pengaruh umur pemanenan dan pemberian dosis pupuk kandang yang optimal dalam usaha meningkatkan dan mempertahankan hasil produksi kangkung darat serta meningkatkan persentase bagian yang dapat dikonsumsi sehingga tidak ada bagian kangkung darat yang terbuang.

\section{METODE PENELITIAN}

Penelitian ini dilaksanakan pada bulan September sampai dengan bulan Oktober 2016 di lahan yang bertempat di Desa Sindon Kecamatan Ngemplak Kabupaten Boyolali. Alat yang digunakan dalam penelitian ini antara lain cangkul, ember, meteran, rafia, baskom, penggaris, gunting, tugal, oven, timbangan analitik dan alat tulis. Bahan yang digunakan antara lain benih kangkung darat (Ipomoea reptans), pupuk kandang dan air.

Penelitian ini menggunakan Rancangan Acak Kelompok Lengkap (RAKL) faktorial. Faktor yang digunakan dalam penelitian ini yaitu terdiri 
dari dua faktor yaitu dosis pupuk kandang dan umur panen. Dosis pupuk kandang yang digunakan yaitu $\mathrm{O} 1$ (0 ton/ha), O2 (6 ton/ha), O3 (8 ton/ha) dan O4 (10 ton/ha), dan perlakuan umur panen yaitu P1 (16 HSS), P2 (20 HSS), dan P3 (24 HSS). Dari dua faktor yang dikombinasikan tersebut diperoleh 12 kombinasi perlakuan dengan ulangan sebanyak 3 kali sehingga diperoleh 36 satuan percobaan. Variabel yang diamati meliputi tinggi tanaman, jumlah daun, panjang ruas, berat segar, berat kering, indeks luas daun dan indeks panen. Data dianalisis menggunakan anova $(\alpha: 0,05)$ dan dilanjutkan dengan uji lanjut DMRT apabila hasil berpengaruh nyata. Analisis korelasi dilakukan untuk mengetahui hubungan antar peubah.

\section{HASIL DAN PEMBAHASAN}

\section{Tinggi Tanaman}

Tabel 1. Rerata Tinggi Tanaman Kangkung Darat $(\mathrm{cm})$ pada Perlakuan beberapa Dosis Pupuk Kandang dan Umur Panen

\begin{tabular}{cccccc}
\hline \multirow{2}{*}{ Umur Panen } & \multicolumn{4}{c}{ Dosis Pupuk Kandang } & \multirow{2}{*}{ Rerata } \\
\cline { 2 - 5 } & 0 ton/ha & 6 ton/ha & 8 ton/ha & 10 ton/ha & \\
\hline 16 HSS & 21,35 & 24,36 & 24,41 & 23,05 & 23,29 a \\
20 HSS & 29,02 & 31,38 & 34,11 & 31,99 & $31,62 \mathrm{~b}$ \\
24 HSS & 39,55 & 35,22 & 44,37 & 43,90 & $40,76 \mathrm{c}$ \\
\hline Rerata & $29,97 \mathrm{a}$ & $30,32 \mathrm{a}$ & $32,98 \mathrm{a}$ & $34,29 \mathrm{a}$ & \\
\hline
\end{tabular}

Keterangan: Rerata yang diikuti notasi (a, b, c, dst) yang sama di masing-masing perlakuan dosis pupuk kandang dan umur panen menunjukkan berbeda tidak nyata pada uji Duncan Multiple Range Test (DMRT) taraf 5\%.

Hasil analisis ragam menunjukkan bahwa interaksi antara perlakuan dosis pupuk kandang dan umur panen tidak berpengaruh nyata terhadap tinggi tanaman kangkung darat $(\mathrm{P}>0,05)$. Berdasarkan hasil uji analisis diperoleh bahwa umur panen berpengaruh nyata terhadap tinggi tanaman kangkung darat. Semakin lama umur panen maka semakin meningkat pula tinggi tanaman (Lugiyo, 2006). Rerata nilai tinggi tanaman tertinggi terdapat pada perlakuan umur panen 24 HSS yaitu sebesar $40,76 \mathrm{~cm}$ dan nilai rerata tinggi tanaman terendah yaitu pada perlakuan umur $16 \mathrm{HSS}$ yaitu sebesar $23,29 \mathrm{~cm}$.
Rosita et al. (2005) menyatakan bahwa pertumbuhan tanaman semakin meningkat dengan bertambahnya umur tanaman. Hal ini dikarenakan semakin lama umur tanaman maka tanaman akan mengalami fase pertumbuhan vegetatif yang cepat (Austin, 2007). Hal ini sesuai dengan pendapat Zulkifli dan Herman (2012) yang menyatakan bahwa saat masa vegetatif, tanaman memproduksi hormon pertumbuhan yang lebih banyak sehingga mampu memacu dominasi apikal tanaman, yang selanjutnya meningkatkan tinggi tanaman. Perlakuan dosis pupuk kandang tidak berpengaruh nyata terhadap tinggi tanaman.

\section{Panjang Ruas}

Tabel 2. Rerata Panjang Ruas Kangkung Darat $(\mathrm{cm})$ pada Perlakuan beberapa Dosis Pupuk Kandang dan Umur Panen

\begin{tabular}{cccccc}
\hline \multirow{2}{*}{ Umur Panen } & \multicolumn{4}{c}{ Dosis Pupuk Kandang } & \multirow{2}{*}{ Rerata } \\
\cline { 2 - 5 } & 0 ton/ha & 6 ton/ha & 8 ton/ha & 10 ton/ha & \\
\hline $16 \mathrm{HSS}$ & 5,04 & 5,57 & 5,65 & 5,52 & $5,45 \mathrm{a}$ \\
$20 \mathrm{HSS}$ & 5,25 & 6,32 & 6,28 & 6,43 & $6,07 \mathrm{ab}$ \\
$24 \mathrm{HSS}$ & 6,15 & 5,94 & 6,30 & 6,70 & $6,27 \mathrm{~b}$ \\
\hline Rerata & $5,48 \mathrm{a}$ & $5,94 \mathrm{a}$ & $6,08 \mathrm{a}$ & $6,22 \mathrm{a}$ & \\
\hline
\end{tabular}

Keterangan: Rerata yang diikuti notasi (a, b, c, dst) yang sama di masing-masing perlakuan dosis pupuk kandang dan umur panen menunjukkan berbeda tidak nyata pada uji beda Duncan Multiple Range Test (DMRT) taraf 5\%. 
Berdasarkan hasil analisis ragam menunjukkan bahwa tidak ada interaksi antara perlakuan dosis pupuk kandang dan umur panen terhadap panjang ruas kangkung darat $(\mathrm{P}>0,05)$. Perlakuan dosis pupuk kandang tidak berpengaruh nyata terhadap panjang ruas kangkung darat. Hal ini dikarenakan pada saat umur tersebut tanaman belum mengalami persaingan dikarenakan umurnya yang relatif pendek. Semua tanaman pada masing-masing perlakuan tumbuh wajar sehingga unsur hara yang di berikan juga dapat dimanfaatkan secara optimal pada masing-masing tanaman karena belum ada pengaruh dari luar.
Perlakuan Umur panen berpengaruh nyata terhadap panjang ruas kangkung darat. Nilai panjang ruas tertinggi terdapat pada perlakuan umur panen 24 HSS yaitu sebesar 6,27, sedangkan nilai panjang ruas terendah pada perlakuan 16 HSS yaitu sebesar 5,45. Panjang ruas berkorelasi sangat nyata positif terhadap tinggi tanaman $(\mathrm{r}: 0,44, \mathrm{p}<0,01, \mathrm{n}: 36)$. Semakin tinggi tanaman maka panjang ruas juga semakin tinggi nilainya. Peningkatan tinggi tanaman berkaitan dengan penambahan kandungan hormon di sekitar sel-sel meristem pucuk sehingga tanaman bertambah tinggi.

\section{Jumlah Daun}

Tabel 3. Rerata Jumlah Daun Kangkung Darat (lembar) pada Perlakuan beberapa Dosis Pupuk Kandang dan Umur Panen

\begin{tabular}{cccccc}
\hline \multirow{2}{*}{ Umur Panen } & \multicolumn{4}{c}{ Dosis Pupuk Kandang } & \multirow{2}{*}{ Rerata } \\
\cline { 2 - 5 } & 0 ton/ha & 6 ton/ha & 8 ton/ha & 10 ton/ha & \\
\hline 16 HSS & 7,33 & 8,07 & 7,53 & 8,00 & $7,73 \mathrm{a}$ \\
20 HSS & 10,20 & 10,60 & 10,53 & 10,20 & $10,38 \mathrm{~b}$ \\
24 HSS & 13,47 & 12,93 & 13,33 & 15,33 & $13,77 \mathrm{c}$ \\
\hline Rerata & $10,33 \mathrm{a}$ & $10,53 \mathrm{a}$ & $10,47 \mathrm{a}$ & $11,18 \mathrm{a}$ & \\
\hline
\end{tabular}

Keterangan: Rerata yang diikuti notasi (a, b, c, dst) yang sama di masing-masing perlakuan dosis pupuk kandang dan umur panen menunjukkan berbeda tidak nyata pada uji Duncan Multiple Range Test (DMRT) taraf 5\%.

Hasil analisis ragam menunjukkan bahwa tidak ada interaksi antara dosis pupuk dan umur panen terhadap jumlah daun kangkung darat $(\mathrm{P}>0,05)$. Perbedaan umur panen berpengaruh nyata terhadap jumlah daun kangkung darat. Jumlah daun terbanyak terdapat pada perlakuan umur panen 24 HSS yaitu sebesar 13,77 dan jumlah daun paling sedikit terdapat pada perlakuan umur panen 16 HSS sebesar 7,73. Semakin lama umur tanaman maka pertumbuhan vegetatif tanaman juga semakin baik sehingga jumlah daun akan semakin banyak. Jumlah daun berkorelasi positif sangat nyata terhadap tinggi tanaman (r:0,93 $\mathrm{p}<0,01 \mathrm{n}: 36$ ), artinya jumlah daun berkaitan sangat erat dengan tinggi tanaman semakin tinggi tanaman maka semakin banyak pula jumlah daun yang tumbuh (Edi, 2014). Peningkatan jumlah daun menunjukkan peningkatan secara kuantitatif seiring dengan meningkatnya umur tanaman yang berhubungan dengan perkembangan sel.

\section{Indeks Luas Daun}

Tabel 4. Rerata Indeks Luas Daun (ILD) Kangkung Darat $\left(\mathrm{m}^{2} / \mathrm{m}^{2}\right)$ pada Perlakuan beberapa Dosis Pupuk Kandang dan Umur Panen

\begin{tabular}{cccccc}
\hline \multirow{2}{*}{ Umur Panen } & \multicolumn{4}{c}{ Dosis Pupuk Kandang } & \multirow{2}{*}{ Rerata } \\
\cline { 2 - 5 } & 0 ton/ha & 6 ton/ha & 8 ton/ha & 10 ton/ha & \\
\hline 16 HSS & 1,30 & 1,54 & 1,67 & 1,46 & $1,49 \mathrm{a}$ \\
$20 \mathrm{HSS}$ & 2,51 & 2,94 & 3,08 & 2,50 & $2,76 \mathrm{~b}$ \\
24 HSS & 3,28 & 2,71 & 3,24 & 3,69 & $3,23 \mathrm{c}$ \\
\hline Rerata & $2,36 \mathrm{a}$ & $2,40 \mathrm{a}$ & $2,66 \mathrm{a}$ & $2,55 \mathrm{a}$ & \\
\hline
\end{tabular}

Keterangan: Rerata yang diikuti notasi (a, b, c, dst) yang sama di masing-masing perlakuan dosis pupuk kandang dan umur panen menunjukkan berbeda tidak nyata pada uji Duncan Multiple Range Test (DMRT) taraf 5\%. 
Hasil analisis ragam menunjukkan tidak adanya interaksi antara perlakuan dosis pupuk kandang dan umur panen terhadap indeks luas daun $(\mathrm{P}>0,05)$. Dosis pupuk kandang tidak berpengaruh nyata terhadap besarnya indeks luas daun. Umur panen berbeda nyata terhadap indeks luas daun. Rerata indeks luas daun tertinggi terdapat terdapat pada perlakuan umur panen 24 HSS sebesar 3,23 dan rerata indeks luas daun terendah terdapat pada perlakuan umur panen 16 HSS sebesar 1,49. Meningkatnya umur tanaman juga meningkatkan ILD (Susanti et al., 2012) tanaman semakin rimbun dan terlihat rapat. Hasil penelitian menunjukkan bahwa semakin lama umur tanaman secara nyata memperbanyak dan memperluas daun. Indeks luas daun berkorelasi sangat nyata positif terhadap tinggi tanaman (r:0,88 p<0,01, n:36) dan Jumlah daun (r:0,89 $\mathrm{p}<0,01, \mathrm{n}: 36)$. Semakin tinggi tanaman dan semakin banyak jumlah daun maka nilai ILD juga semakin meningkat.

\section{Berat Segar}

Tabel 5. Rerata Berat Segar Kangkung Darat (gram) pada Perlakuan beberapa Dosis Pupuk Kandang dan Umur Panen

\begin{tabular}{cccccc}
\hline \multirow{2}{*}{ Umur Panen } & \multicolumn{4}{c}{ Dosis Pupuk Kandang } & \multirow{2}{*}{ Rerata } \\
\cline { 2 - 5 } & 0 ton/ha & 6 ton/ha & 8 ton/ha & 10 ton/ha & \\
\hline 16 HSS & 13,38 & 18,01 & 14,08 & 16,25 & $15,48 \mathrm{a}$ \\
$20 \mathrm{HSS}$ & 26,92 & 34,99 & 41,70 & 35,57 & $34,79 \mathrm{~b}$ \\
24 HSS & 60,03 & 51,46 & 54,84 & 80,67 & $61,75 \mathrm{c}$ \\
\hline Rerata & $33,45 \mathrm{a}$ & $34,82 \mathrm{a}$ & $36,87 \mathrm{a}$ & $44,23 \mathrm{a}$ & \\
\hline
\end{tabular}

Keterangan: Rerata yang diikuti notasi (a, b, c, dst) yang sama di masing-masing perlakuan dosis pupuk kandang dan umur panen menunjukkan berbeda tidak nyata pada uji Duncan Multiple Range Test (DMRT) 5\%.

Hasil analisis ragam menunjukkan bahwa tidak ada interaksi antara dosis pupuk kandang dan umur panen terhadap berat segar kangkung darat $(\mathrm{P}>0,05)$. Perbedaan dosis pupuk kandang tidak mempengaruhi berat segar tanaman kangkung darat. Umur panen berpengaruh nyata terhadap berat segar tanaman kangkung darat. Rerata berat segar tertinggi terdapat pada perlakuan umur panen 24 HSS yaitu sebesar 52,96 dan rerata berat segar terendah yaitu pada perlakuan umur panen 16 HSS yaitu sebesar 11,89 . Tanaman yang memiliki umur yang lebih lama memiliki bagian-bagian tubuh yang lebih besar karena pertumbuhan vegetatif yang semakin optimal. Menurut Lingga dan Marsono (2008), tinggi rendahnya bahan segar tanaman tergantung pada penyerapan air dan unsur hara yang terdapat dalam tanah. Variable berat segar tanaman berkorelasi sangat nyata positif terhadap tinggi tanaman (r:0,85, p<0,01, n:36), jumlah daun $(\mathrm{r}: 0,86 \mathrm{p}<0,01, \mathrm{n}: 36)$, indeks luas daun (r:0,83 $\mathrm{p}<0,01, \mathrm{n}: 36)$ dan berkorelasi nyata positif terhadap panjang ruas (r:0,33 p<0,01, n:36). Hal ini menunjukkan bahwa semakin meningkat tinggi tanaman, jumlah daun, indeks luas daun serta panjang ruas maka semakin meningkat pula berat segar dari tanaman kangkung darat.

\section{Berat Kering}

Tabel 6. Rerata Berat Kering Kangkung Darat (gram) pada Perlakuan beberapa Dosis Pupuk Kandang dan Umur Panen

\begin{tabular}{cccccc}
\hline \multirow{2}{*}{ Umur Panen } & \multicolumn{4}{c}{ Dosis Pupuk Kandang } & \multirow{2}{*}{ Rerata } \\
\cline { 2 - 5 } & 0 ton/ha & 6 ton/ha & 8 ton/ha & 10 ton/ha & \\
\hline 16 HSS & 1,02 & 1,59 & 1,30 & 1,55 & $1,37 \mathrm{a}$ \\
$20 \mathrm{HSS}$ & 1,77 & 2,02 & 2,80 & 2,28 & $2,22 \mathrm{~b}$ \\
$24 \mathrm{HSS}$ & 1,86 & 2,12 & 2,95 & 3,62 & $2,64 \mathrm{c}$ \\
\hline Rerata & $1,55 \mathrm{a}$ & $1,91 \mathrm{ab}$ & $2,35 \mathrm{bc}$ & $2,48 \mathrm{c}$ & \\
\hline
\end{tabular}

Keterangan: Rerata yang diikuti notasi (a, b, c, dst) yang sama di masing-masing perlakuan dosis pupuk kandang dan umur panen menunjukkan berbeda tidak nyata pada uji Duncan Multiple Range Test (DMRT) taraf 5\%. 
Hasil analisis ragam menunjukkan bahwa tidak adai interaksi antara perlakuan dosis pupuk kandang dan umur panen terhadap berat kering kangkung darat $(\mathrm{P}>0,05)$. Perlakuan umur panen berpengaruh nyata terhadap berat kering tanaman kangkung darat. Hasil rerata berat kering tertinggi pada umur panen 24 HSS sbesar 2,64 dan terendah pada umur panen 16 HSS sebesar 1,37. Perlakuan dosis pupuk kandang juga berpengaruh nyata terhadap berat kering tanaman kangkung darat. Nilai terendah terdapat pada dosis 0 ton/ha yaitu sebesar 1,55 gram dan hasil tertinggi terdapat pada perlakuan 10 ton/ha yaitu sebesar 2,64 gram. Hal ini menunjukkan bahwa semakin lama umur panen dan semakin tinggi dosis pupuk kandang menyebabkan berat kering juga semakin meningkat (Rahardjo et al., 2004). Berat kering berkorelasi sangat nyata positif dengan tinggi tanaman (r:0,76 $\mathrm{p}<0,01, \mathrm{n}: 36$ ), jumlah daun $(\mathrm{r}: 0,72 \mathrm{p}<0,01, \mathrm{n}: 36)$, indeks luas daun (r:0,70 $\mathrm{p}<0,01, n: 36)$, berat segar (r:0,65 $\mathrm{p}<0,01, \mathrm{n}: 36)$, serta berkorelasi nyata positif dengan panjang ruas (r:0,40, p<0,05, n:36).

\section{Indeks Panen}

Tabel 7. Rerata Indeks Panen Kangkung Darat pada Perlakuan beberapa Dosis Pupuk Kandang dan Umur Panen

\begin{tabular}{cccccc}
\hline \multirow{2}{*}{ Umur Panen } & \multicolumn{4}{c}{ Dosis Pupuk Kandang } & \multirow{2}{*}{ Rerata } \\
\cline { 2 - 5 } & 0 ton/ha & 6 ton/ha & 8 ton/ha & 10 ton/ha & \\
\hline 16 HSS & 0,82 & 0,83 & 0,82 & 0,84 & $0,83 \mathrm{~b}$ \\
20 HSS & 0,59 & 0,56 & 0,60 & 0,59 & $0,59 \mathrm{a}$ \\
$24 \mathrm{HSS}$ & 0,59 & 0,56 & 0,59 & 0,57 & $0,58 \mathrm{a}$ \\
\hline Rerata & $0,67 \mathrm{a}$ & $0,65 \mathrm{a}$ & $0,67 \mathrm{a}$ & $0,67 \mathrm{a}$ & \\
\hline
\end{tabular}

Keterangan: Rerata yang diikuti notasi (a, b, c, dst) yang sama di masing- masing perlakuan dosis pupuk kandang dan umur panen menunjukkan berbeda tidak nyata pada uji Duncan Multiple Range Test (DMRT) taraf 5\%.

Tabel 8. Rerata Berat Kangkung Darat yang dapat Dikonsumsi (gram) pada Perlakuan beberapa Dosis Pupuk Kandang dan Umur Panen

\begin{tabular}{cccccc}
\hline \multirow{2}{*}{ Umur Panen } & \multicolumn{4}{c}{ Dosis Pupuk Kandang } & \multirow{2}{*}{ Rerata } \\
\cline { 2 - 5 } & 0 ton/ha & 6 ton/ha & 8 ton/ha & 10 ton/ha & \\
\hline 16 HSS & 10,96 & 15,20 & 11,59 & 13,86 & $12,90 \mathrm{a}$ \\
$20 \mathrm{HSS}$ & 16,00 & 19,99 & 24,71 & 21,18 & $20,47 \mathrm{~b}$ \\
24 HSS & 36,49 & 28,12 & 32,60 & 44,73 & $35,48 \mathrm{c}$ \\
\hline Rerata & $21,15 \mathrm{a}$ & $21,10 \mathrm{a}$ & $22,97 \mathrm{a}$ & $26,59 \mathrm{a}$ & \\
\hline
\end{tabular}

Keterangan: Rerata yang diikuti notasi (a, b, c, dst) yang sama di masing- masing perlakuan dosis pupuk kandang dan umur panen menunjukkan berbeda tidak nyata pada uji Duncan Multiple Range Test (DMRT) taraf 5\%.

Hasil analisis ragam menunjukkan bahwa tidak adanya interaksi antara perlakuan dosis pupuk kandang dan umur panen terhadap indeks panen kangkung darat $(\mathrm{P}>0,05)$. Dosis pupuk kandang tidak berpengaruh nyata terhadap indeks panen pada tanaman kangkung darat (Tabel 7). Perlakuan umur panen menunjukkan hasil beda nyata terhadap indeks panen (Tabel 7). Hal ini dikarenakan semakin lama umur tanaman maka semakin mengeras pula bagian vegetatif tanaman sehingga tidak layak untuk di konsumsi. Pernyataan tersebut sesuai dengan pendapat Rubatzky dan Yamaguchi (1998) yang menyatakan bahwa semakin lama umur panen maka indeks panen akan semakin sedikit. Hal ini disebabkan semakin banyak bagian-bagian yang sukulen, mengeras dan berserat.

Tabel 8 menunjukkan rerata berat kangkung darat yang dapat dikonsumsi untuk perhitungan indeks panen dan dinyatakan dalam gram. Dosis pupuk kandang tidak memberikan pengaruh yang nyata terhadap berat kangkung darat yang dapat di konsumsi. Pada perlakuan umur panen semakin lama umur tanaman maka semakin tinggi nilai berat konsumsinya. Terlihat pada perlakuan umur panen 24 HSS mempunyai nilai berat yang dapat di konsumsi (gram) yang lebih tinggi yaitu 35,48 gram $(9,59$ ton/ha) dibanding dengan perlakuan 
umur panen 16 HSS yaitu 12,90 (3,49 ton/ha) gram dan 20 HSS yaitu 20,47 gram (5,54 ton/ha). Hal ini berkaitan dengan bagian yang dipanen berupa bagian vegetatif yaitu batang dan daun yang semakin meningkat pula. Bagian yang dapat dikonsumsi dan indeks panen mempunyai hubungan yang berbanding terbalik dengan nilai korelasi sangat nyata negative (r:-0,48, $\mathrm{p}<0,01$ $\mathrm{n}: 36)$. Semakin muda umur tanaman maka indeks panen semakin tinggi, sedangkan beratnya rendah yaitu pada umur $16 \mathrm{HSS}$, sedangkan semakin tua umur tanaman berat kangkung yang dapat dikonsumsi semakin tinggi namun indeks panen semakin rendah yaitu pada umur 24 HSS.

\section{KESIMPULAN DAN SARAN}

\section{Kesimpulan}

Tidak ada interaksi antara dosis pupuk kandang dan umur panen terhadap produksi baby kangkung. Dosis pupuk kandang hanya berpengaruh nyata terhadap berat kering tanaman kangkung darat. Umur panen berpengaruh nyata terhadap tinggi tanaman, panjang ruas, jumlah daun, indeks luas daun, berat segar, berat kering, dan indeks panen. Umur panen 24 HSS menghasilkan pertumbuhan lebih tinggi dibandingkan dengan umur panen 16 HSS dan 20 HSS yaitu pada variabel tinggi tanaman, panjang ruas, jumlah daun, indeks luas daun, berat segar sebesar 61,75 gram (16,69 ton/ha) dan berat kering, namun dari variabel indeks panen perlakuan 16 HSS lebih tinggi untuk baby kangkung darat yaitu sebesar 0,83. Pupuk kandang 10 ton/ha dan umur panen 16 HSS menghasilkan tanaman baby kangkung darat yang dapat dikonsumsi hampir pada semua bagian tanamannya dengan indeks panen tertinggi yaitu sebesar 0,83 .

\section{Saran}

Saran yang dapat diberikan untuk penelitian ini, sebaiknya dilakukan penelitian lebih lanjut mengenai umur panen minimal kangkung darat sehingga dapat dikatakan baby kangkung darat. Hal ini dikarenakan paada penelitian ini indeks panen dari baby kangkung darat yang targetnya adalah hampir $100 \%$ hanya mencapai $80 \%$. Selain itu perlu diadakan analisis tanah yang lebih lengkap mengenai unsur makro agar diketahui unsur apa yang mempengaruhi pertumbuhan dan perkembangan tanaman kangkung darat, sehingga dosis pupuk kandang dapat disesuaikan. Serta dilakukan treatment lain untuk menghasilkan tanaman kualitas yang tinggi dengan bagian konsumsi yang tinggi pula.

\section{DAFTAR PUSTAKA}

Austin, F.D. 2007. Water Spinach (Ipomoea Aquatic, Convolvulaceae) a Food Gone Wild. Etnonobotany Research and Applications. 5, 123-146.

Edi, S., \& Yusri, A. 2009. Budidaya Kangkung Darat Semi Organik. Jambi. Balai Pegkajian Teknologi Pertanian.

Edi, S. 2014. Pengaruh Pemberian Pupuk Organik terhadap Pertumbuhan dan Hasil Tanaman Kangkung Darat (Ipomoea reptans Poir). Bioplantae. 3(1), 17-24.

Lingga, P., \& Marsono. 2001. Petunjuk Penggunaan Pupuk. Jakarta: Penebar Swadaya.

Lugiyo. 2006. Pengaruh Umur Pemotongan terhadap Produksi Hijauan Rumput Sorghum sp sebagai tanaman pakan ternak. Bogor: Balai Penelitian Ternak.

Nurjanah, Abdullah, A., \& Sudirman, S. 2014. Aktivitas Antioksidan dan Komponen Bioaktif Kangkung Darat Air (Ipomoea aquatic Forsk.). J. Inovasi dan Kewirausahaan. 3(1), 68-75.

Polii, M.G.M. 2009. Respon Produksi Tanaman Kangkung Darat Darat (Ipomoea reptans Poir) terhadap Variasi Waktu Pemberian Pupuk Kotoran Ayam. J. Soil Environment. (1), 1822.

Rahardjo M., Rosita SMD, \& Sudiarto. 2004. Peranan Populasi Tanaman terhadap Produktivitas Bangle (Zingiber purpureum Roxb.). J. Bahan Alam Indonesia. 3(1), 165170.

Rosita M.S.D., Mono, R., \& Kosasih. 2005. Pola Pertumbuhan dan Serapan Hara N, P, K Tanaman Bangle (Zingiber purpureum Roxb.) J. Littri. 11(1), 32-36.

Rubatzky, V.E., \& Yamaguchi, M. 1998. Principles, Production, and Nutritive Values (Penerjemah: Catur Herison). Bandung: ITB Press. 320 hal.

Susanti, E.D., Purbajanti, \& Sutarno. 2012. Pertumbuhan Hijauan Kacang Pintoi (Arachis pintoi) pada berbagai Panjang Stek dan Dosis 
Pupuk Organik Cairperiode Pemotongan Kedua. J. Animal Agriculture. 1(1), 72-731.

Zulkifli, \& Herman. 2012. Respon Jagung Manis (Zea mays saccharata, Sturt) terhadap Dosis dan Jenis Pupuk Organik. Jurnal Agroteknologi. 2(2), 33-36. 